\title{
Archaea and Bacteria in deep lake hypolimnion: in situ dark inorganic carbon uptake
}

\author{
Cristiana CALLIERI, ${ }^{1 *}$ Manuela COCI, ${ }^{1}$ Ester M. ECKERT, ${ }^{2}$ Michaela M. SALCHER, ${ }^{2}$ Roberto BERTONI ${ }^{1}$ \\ ${ }^{1}$ CNR - Institute of Ecosystem Study, Largo Tonolli 50, 28922 Verbania Pallanza, Italy; ${ }^{2}$ Limnological Station, Institute of Plant \\ Biology, University of Zurich, Seestrasse 187, 8802 Kilchberg, Switzerland \\ *Corresponding author: c.callieri@ise.cnr.it
}

\begin{abstract}
The interest for microorganisms inhabiting the hypolimnion and for their role in biogeochemical cycles of lakes is considerable, but knowledge is far from complete. The presence of chemolithoautotrophic Bacteria and mesophilic Archaea (e.g., Thaumarchaeota) assimilating inorganic carbon in the deep hypolimnion of lakes has been ascertained. We measured, for the first time at $350 \mathrm{~m}$ in Lake Maggiore (Northern Italy), the prokaryotic in situ dark $\left[{ }^{14} \mathrm{C}\right] \mathrm{HCO}_{3}$ incorporation with a new custom-made apparatus, which takes samples and adds tracers in situ. Thereby stress factors affecting prokaryotes during sample recovery from the depth were avoided. We tested the new instrument at different depths and conditions, performing parallel conventional on board incubations. We found that dark $\left[{ }^{14} \mathrm{C}_{\mathrm{HCO}}\right.$ incorporations had lower standard deviation in in situ incubations with respect to the on board ones, but their means were not statistically different. At $350 \mathrm{~m}$ we estimated an uptake of $187.7 \pm 15 \mu \mathrm{g} \mathrm{C} \mathrm{m}^{-3} \mathrm{~d}^{-1}$, which is in line with the published uptake rates in aquatic systems. By inhibiting the bacterial metabolism, we found that Archaea were responsible for $28 \%$ of the total $\mathrm{CO}_{2}$ uptake. At the same depth, Thaumarchaeota, on average, constituted $11 \%$ of total DAPI counts. Dark $\left[{ }^{14} \mathrm{C}_{\mathrm{H}} \mathrm{HCO} \mathrm{O}_{3}\right.$ incorporation integrated along the aphotic water column was $65.8 \pm 5.2 \mathrm{mg} \mathrm{C} \mathrm{m}^{-2} \mathrm{~d}^{-1}$ which corresponds to $87 \%$ of picophytoplanktonic autotrophic fixation in the euphotic layer. This study provides the first evidence of Bacteria and Archaea dark $\mathrm{CO}_{2}$ fixation in the deep hypolimnion of a subalpine lake and indicates a potentially significant prokaryotic $\mathrm{CO}_{2}$ sink.
\end{abstract}

Key words: Archaea and Bacteria, Thaumarchaeota, dark inorganic carbon uptake, Lake Maggiore, hypolimnion.

Received: December 2013. Accepted: January 2014.

\section{INTRODUCTION}

The hypolimnion of deep lakes is a significant freshwater volume, which has received attention in the early 2000 s as a sensitive indicator for climate warming (Ambrosetti and Barbanti, 1999; Dokulil et al., 2006). Since most studies have centered on epilimnetic microbes the knowledge on prokaryotes inhabiting the dark hypolimnion is comparatively scarce (Newton et al., 2001; Okazaki et al., 2013; Salcher et al., 2011). In particular, the ecological function of hypolimnetic prokaryotes in the carbon cycle are so far understudied.

The presence of mesophilic Thaumarchaeota (formerly: Crenarchaeota) (Brochier-Armanet et al., 2008) has been ascertained in the deep oxygenated hypolimnion of Crater Lake (589 m) (Urbach et al., 2001), of Lake Maggiore (372 m) (Callieri et al., 2009) and in the moderately deep (73 m) high altitude Lake Redon (Auguet et $a l ., 2012)$. Thaumarchaeota have also been found in the epilimnion and upper hypolimnion ( $\sim 50 \mathrm{~m})$ of Laurentian Great Lakes in North America, African Lake Victoria, and Lakes Ladoga and Onega in Northeastern Eurasia (Keough et al., 2003), and in a hypertrophic saline lake (La Cono et al., 2013). Moreover, Thaumarchaeota are widespread among marine systems, e.g., in the Pacific
Ocean (Karner et al., 2001), in the Atlantic Ocean (Teira et al., 2006; Schattenhofer et al., 2009), and in the Mediterranean Sea (Yakimov et al., 2011).

In the 16S rRNA-based tree Thaumarchaeota clearly separate from Euryarchaeota and comprise, among others, Marine Group I (MGI.1a), which are commonly found in oceanic and freshwater plankton (formerly 1.1a Crenarchaeota) (Pester et al., 2011). Members of the MGI.1a clade were abundant in deeper water layers of a high-altitude lake during stratification whereas the clade SAGMGC-1, closely related to MGI.1a, was retrieved in high densities in the neuston and in surface water layers during winter (Auguet et al., 2012).

The discovery of putative genes for the ammoniamonooxygenase alpha-subunit (amoA) exclusive for Thaumarchaeota (Venter et al., 2004) gave a hint to their ecological importance, by emphasizing their role in the first step of nitrification and their possible competition with nitrifying Bacteria. Even though amoA gene frequency hints to the ecological function of ammonia-oxidizing prokaryotes, it does not demonstrate their metabolic activity and gives only very indirect evidence of their role in carbon cycling. A more direct estimate of prokaryotic activity can be achieved by measurements of 
tracer incorporation, such as dark $\left[{ }^{14} \mathrm{C}^{-} \mathrm{HCO}_{3}\right.$ assimilation. Inorganic carbon assimilation can be performed by chemoautotrophs affiliated with Bacteria and Archaea, albeit using different pathways. Chemolithoautotrophic Bacteria can incorporate $\mathrm{CO}_{2}$ in the dark through a variety of carboxylation reactions to fulfill diverse metabolic requirements such as anaplerotic demands or synthesis of fatty acids, nucleotides and amino acids (Casamayor et al., 2012). Thaumarchaeota can use the hydroxypropionate-hydroxybutyrate carbon assimilation pathway and reduced nitrogen compounds as energy source, fueling the autotrophic metabolism (Berg et al., 2007).

To date, all dark $\mathrm{CO}_{2}$ fixation measurements in hypolimnia of deep lakes or in oceans have been done by taking samples and incubating on deck or in incubation chambers (Herndl et al., 2005; Yakimov et al., 2011). This procedure hampers an accurate assessment of the activity of the deep layers, since changes in pressure, temperature, and light exposure may cause stress on prokaryotic communities. Therefore we invested in planning and constructing a device for in situ incubations, and measured dark $\left[{ }^{14} \mathrm{C}\right] \mathrm{HCO}_{3}$ incorporation. On board measurements were performed in parallel and used in order to test the instrument in different conditions. Our apparatus was designed for in situ incubation and therefore avoids the decompression of the samples from great depths as it automatically takes water-sample, adds the tracers and stays at the chosen depth during the whole incubation time. With this apparatus we assessed the putative archaeal in situ dark $\left[{ }^{14} \mathrm{C}\right] \mathrm{HCO}_{3}$ incorporation in the deep oxygenated hypolimnion of a subalpine lake by inhibiting the bacterial metabolism and calculating their contribution to the total $\mathrm{CO}_{2}$ uptake. At the same depth we counted Thaumarchaeota 1.1a (from now on referred to as Thaumarchaeota) and Bacteria using CARD-FISH and estimated their contribution to prokaryote abundance. For the study, we have selected Lake Maggiore because Thaumarchaeota presence along its water column has already been studied (Callieri et al., 2009) and because the lake is regularly monitored since 1980 (Bertoni et al., 2010).

\section{METHODS}

\section{Site description}

Lake Maggiore is a large, deep, subalpine lake (212 $\mathrm{km}^{2}, \mathrm{Z}_{\max } 370 \mathrm{~m}$ ) located in Northern Italy, and belongs to the Long-Term Ecological Research (LTER) network as Southern Alpine Lake. Long-term physical, chemical and biological data are available (Salmaso et al., 2012). The lake recovered from a eutrophic state, which culminated in the late 1970s, and is now oligo-mesotrophic with total phosphorus around $10 \mu \mathrm{g} \mathrm{L}^{-1}$ (Bertoni et al., 2004; Salmaso et al., 2006). Lake Maggiore is holo-oligomictic and the complete turnover only takes place in winters with strong wind and low air temperatures. Nevertheless the hypolimnion is always oxygenated due to river and littoral water intrusions into deep layers (Ambrosetti et al., 2003). During this study the oxygen profiles showed oxic condition of the water column with concentrations ranging from 8.6 to $12 \mathrm{mg} \mathrm{O}_{2} \mathrm{~L}^{-1}$. The temperature profiles indicated persistence of the stratification from June to October.

\section{In situ and on board incubations}

In situ incubations were performed with a new custom-made device (Fig. 1) suspended at the selected depth. The new device was tested by making parallel in situ and
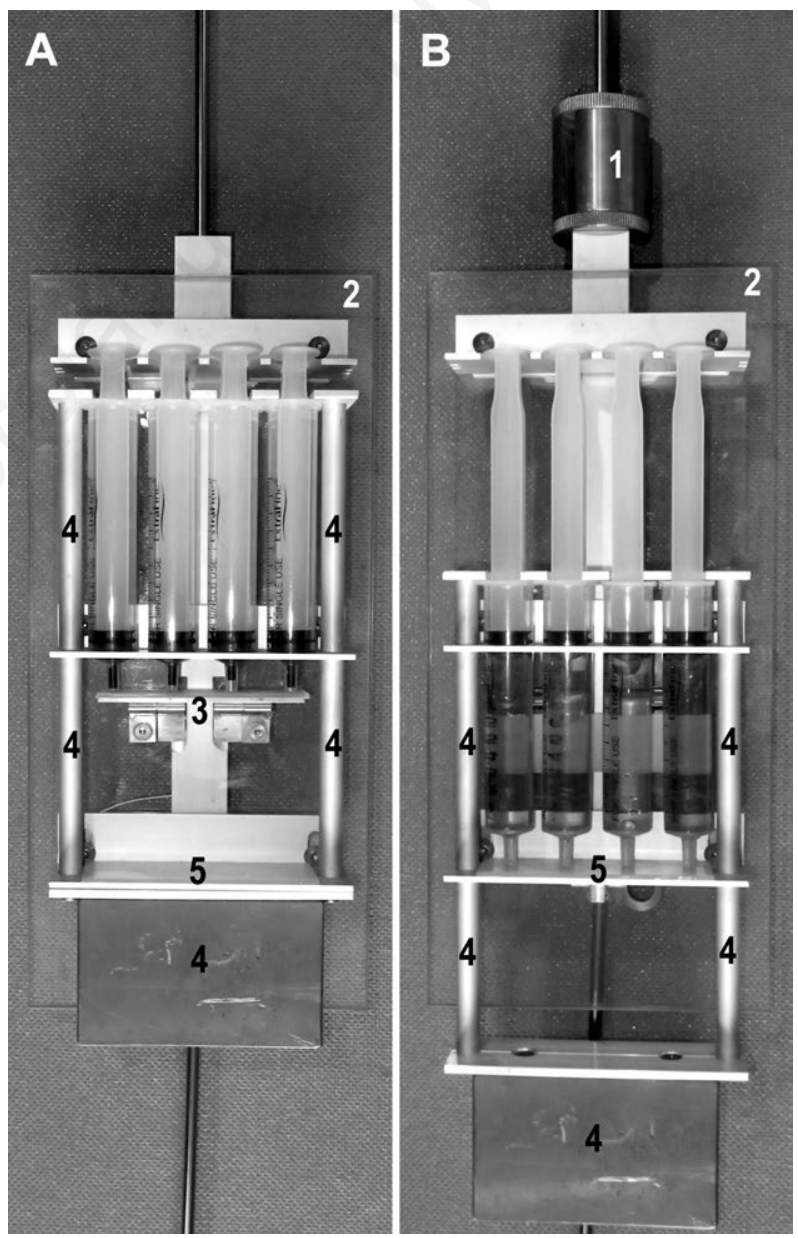

Fig. 1. Custom-made instrument for in situ incubation in deep waters (see Methods for a detailed description). A) Image of the instrument before sampling with syringes loaded with tracers. B) Image of instrument after sampling and during incubation time, with syringes filled with sample. 1, Messenger; 2, acrylic frame; 3 , pivoting frame closing the tips of syringes until the messenger is released; 4 , sliding cursor pulling down the bodies of the syringes; 5 , fixed frame covered by a silicon layer closing the tip of the syringes after sampling and during the incubation. 
on board measurements of $\left[{ }^{14} \mathrm{C}\right] \mathrm{HCO}_{3}$ uptake at different stations, months and hypolimnetic depths in Lake Maggiore (Tab. 1), in the year 2010. The two sampling stations were Ghiffa $\left(45^{\circ} 56^{\prime} \mathrm{N}, 8^{\circ} 38^{\prime} \mathrm{E}\right)$ at the deepest point (maximum depth $370 \mathrm{~m}$ ), and Maggia $\left(46^{\circ} 08^{\prime} \mathrm{N}, 8^{\circ} 46^{\prime} \mathrm{E}\right)$ located close to the homonymous river outflow, a source of potential allochthonous input. These different stations, months and depths provided various conditions for testing the instrument. In the following year (2011) total dark $\left[{ }^{14} \mathrm{C}\right] \mathrm{HCO}_{3}$ uptake was measured only in situ, at Ghiffa station, at $350 \mathrm{~m}$, to separate the Archaea activity from the total, using appropriate treatments as described in details below.

The device, operated by a messenger, allowed in situ sample collection, tracer addition, and incubation in deep waters because it can be maintained at the selected depth. The instrument is composed of an acrylic rectangular frame provided with a syringe holder to accommodate 4 plastic disposable syringes ( 3 replicates and 1 control) of $50 \mathrm{~mL}$ volume. The syringes were prepared in the laboratory by introducing the tracers and the metabolic inhibitors in the replicates and the fixative in the control. After adjusting the plunger of each syringe keeping their content on the edge of the tip, the syringes were placed in the syringe holder and fixed to the frame. The bodies of the syringes were engaged in a sliding cursor and kept in place by a pivoting frame, thus closing the tips of syringes until the beginning of the incubation. The pivoting frame was kept in a fixed position by a trigger mechanism; when the trigger was operated through the release of a messenger, the pivoting frame freed the ends of the syringes. Incubations started when the sliding cursor pulled down by gravity filling the syringes with water samples and adding the tracer to it. The run of the syringe body stopped at a fixed frame covered by a silicon layer. The device was left at the sampling depth suspended to a buoy and recovered after $6 \mathrm{~h}$ of incubation.

The samples for on board incubations were taken with a Niskin bottle; tracers and fixative were added immediately after sampling. Incubations were performed in triplicate $50 \mathrm{~mL}$ Falcon $^{\circledR}$ tubes kept in thermo boxes pre-filled with water collected from the same depths and kept at in situ temperature in the dark.

\section{Measurements of dark $\left[{ }^{14} \mathrm{C}\right] \mathrm{HCO}_{3}$ uptake}

We used labeled $\left[{ }^{14} \mathrm{C}\right] \mathrm{HCO}_{3}$ with a specific activity of $52 \mathrm{mCi} \mathrm{mmol}^{-1}$ (PerkinElmer, Life Sciences) according to the protocol of Steeman-Nielsen (1951). Triplicate samples of $50 \mathrm{~mL}$ were amended with $500 \mu \mathrm{L}\left[{ }^{14} \mathrm{C}\right] \mathrm{HCO}_{3}(10$ $\mu \mathrm{Ci}$ ), to have a final activity of $0.2 \mu \mathrm{Ci} \mathrm{mL}-1$. Controls were fixed with $2.5 \mathrm{~mL}$ of filtered formaldehyde $(2 \%$ $[\mathrm{v} / \mathrm{v}]$, final concentration). To avoid $\left[{ }^{14} \mathrm{C}\right] \mathrm{HCO}_{3}$ losses, after addition of the fixative, appropriate aliquots of $\mathrm{NaHCO}_{3}$ at $\mathrm{pH} 9.5$ were added to the syringes for the in situ incubations.

To measure the total and non-bacterial in situ dark $\left[{ }^{14} \mathrm{C}\right] \mathrm{HCO}_{3}$ uptake we used two custom-made devices suspended at $350 \mathrm{~m}$. One was utilized to measure the total dark uptake and the second to assess the non-bacterial dark $\left[{ }^{14} \mathrm{C}\right] \mathrm{HCO}_{3}$ uptake by inhibiting bacterial activity with metabolic inhibitors. The first device was loaded with 500 $\mu \mathrm{L}$ of $\left[{ }^{14} \mathrm{C}\right] \mathrm{HCO}_{3}$ to triplicate syringes, as described above. The three syringes of the second device were all amended with $500 \mu \mathrm{L}\left[{ }^{14} \mathrm{C}\right] \mathrm{HCO}_{3}, 120 \mu \mathrm{L}$ sodium azide (SA) $10 \mathrm{mM}$ $\left(25 \mu \mathrm{M} \mathrm{L}^{-1}\right.$ ), and $400 \mu \mathrm{L}$ allylthiourea (ATU) $10 \mathrm{mM}$ (86 $\left.\mu \mathrm{M} \mathrm{L}^{-1}\right)$. At these concentrations, ATU inhibits the bacterial monooxygenase and $\mathrm{SA}$ is a selective bacteriostatic agent that inhibits ammonia and nitrite oxidation of Gram-negative bacteria (Ginestet et al., 1998; Santoro and Casciotti, 2011); they both have been successfully used in similar experiments (Yakimov et al., 2011). In the control $\mathrm{pH}$ adjustment necessary to avoid $\mathrm{CO}_{2}$ loss was performed with $\mathrm{NaHCO}_{3}$ as described above.

The total activity of $\left[{ }^{14} \mathrm{C}\right]$ added was measured in the laboratory for each sample and control to obtain accurate $\left[{ }^{14} \mathrm{C}\right] \mathrm{HCO}_{3}$ concentrations. Briefly, $6 \mathrm{~mL}$ of scintillation liquid (Instangel, Beckman) were added to $1 \mathrm{~mL}$ sample and immediately counted in a Beckman LS6000 scintillation counter. The remaining sample was then filtered over $0.22 \mu \mathrm{m}$ polycarbonate filters (Poretics, $25 \mathrm{~mm}$ diameter) in Swinnex ${ }^{\circledR}$ Millipore filter holders and with dis-

Tab. 1. In situ dark $\left[{ }^{14} \mathrm{C}\right] \mathrm{HCO}_{3}$ uptake performed with the new instrument tested $v s$ on board incubation. The measurements were done in Lake Maggiore at two stations (Maggia and Ghiffa), at different depths and months.

\begin{tabular}{|c|c|c|c|c|c|c|}
\hline \multirow[b]{3}{*}{ Station } & \multirow[b]{3}{*}{ Month } & \multirow{3}{*}{$\begin{array}{c}\text { Depth } \\
\text { m }\end{array}$} & \multicolumn{4}{|c|}{ Dark $\left[{ }^{14} \mathrm{C}\right] \mathrm{HCO}_{3}$ uptake $\left(\mu \mathrm{g} \mathrm{C} \mathrm{m}{ }^{-3} \mathrm{~h}^{-1}\right)$} \\
\hline & & & \multicolumn{2}{|c|}{ In situ } & \multicolumn{2}{|c|}{ On board } \\
\hline & & & Mean & $\pm \mathrm{sd}$ & Mean & $\pm \mathrm{sd}$ \\
\hline Maggia & July & 100 & 8.8 & 0.6 & 25.2 & 12.9 \\
\hline Maggia & July & 200 & 9.4 & 1.5 & 5.2 & 1.8 \\
\hline Ghiffa & October & 300 & 7.4 & na & 16.3 & 4.0 \\
\hline Ghiffa & August & 350 & 8.3 & 2.2 & 2.9 & 0.7 \\
\hline
\end{tabular}

sd, standard deviation; na, not available. 
posable plastic syringes. Filters were acidified with 200 $\mu \mathrm{L} 1 \mathrm{~N} \mathrm{HCl}$, kept under the hood for $60 \mathrm{~min}$ to eliminate the inorganic fraction as $\left[{ }^{14} \mathrm{C}\right]$ labeled $\mathrm{CO}_{2}$. Then, $5 \mathrm{~mL}$ scintillation liquid (Filter Count, Beckman) were added to the filters and samples were counted in the scintillation counter for maximum $10 \mathrm{~min}$. The counts per minute $(\mathrm{cpm})$ were automatically corrected to obtain disintegration per minutes $(\mathrm{dpm})$ using the $\left[{ }^{14} \mathrm{C}\right]$ reference standard with a quenching around zero. The efficiency of the conversion was on average $95 \%$ and the luminescence near $0 \%$. Inorganic carbon dark uptake was calculated based on the dpm of the total activity, the dpm of the filters and the dissolved inorganic carbon (DIC) of each sample following a previously described protocol (Callieri and Stockner, 2002) using a Shimadzu 5000A apparatus. Statistical analyses to estimate the difference between in situ and on board incubation were performed with GraphPad Statistics, Prism package, 2007.

\section{Fluorescence in situ hybridization catalyzed reporter deposition (CARD-FISH) and DAPI counting}

Parallel to the in situ dark $\left[{ }^{14} \mathrm{C}\right] \mathrm{HCO}_{3}$ uptake measurements performed in 2011, samples from $350 \mathrm{~m}$ were analysed for prokaryote abundance (DAPI counting) and community composition (CARD-FISH). Samples were fixed with $0.2 \mu \mathrm{m}$ filtered paraformaldehyde $(2 \%[\mathrm{w} / \mathrm{v}]$, final concentration) according to Pernthaler et al. (2004) and Teira et al. (2004). Aliquots of 6-12 mL were filtered onto $0.2 \mu \mathrm{m}$ polycarbonate filters (Poretics, $47 \mathrm{~mm}$ filter diameter), rinsed twice with deionized water, embedded in low melting point agarose, air dried and stored at $-20^{\circ} \mathrm{C}$ until further processing. Filters were cut in sections and selected sections were treated for cell permeabilization with lysozyme or proteinase $\mathrm{K}$ (for Bacteria and Thaumarchaeota probes, respectively) according to the protocol by Teira et al. (2004). The following oligonucleotide probes were used: EUB I-III, for all Bacteria (Daims et al., 1999; Amann and Fuchs, 2008), Cren537, for Thaumarchaeota MGI.1a (Teira et al., 2004; Herndl et al., 2005) and Non338 as negative control for Bacteria (Thermo-Hybrid, Germany). Filter sections were hybridized with HRP- (horseradish-peroxidase) labeled probes and Alexa488-labeled tyramide was used for signal amplification. Filters were counterstained with DAPI, embedded in Citifluor (Citifluor Ltd., London, UK), and inspected under an epifluorescence microscope (Zeiss Axioplan) equipped with filter sets for DAPI (BP365, FT395, LP420) and for Alexa488 (BP450-490, FT510, LP520). Filter sections were analyzed by fully automated high-throughput microscopy (Zeder and Pernthaler, 2009) by capturing 3 pictures from the same field corresponding to total DAPI-stained cells, cells stained with the specific probe, and auto-fluorescence of cyanobacteria and debris. All images were analyzed with the image analysis free- ware ACMEtool (http: $\mid$ www.technobiology.ch), and interfering autofluorescent cyanobacteria or debris were individually subtracted from images of hybridized cells. At least 10 high quality images or $>1000$ DAPI stained cells were analyzed per sample.

For total prokaryotic cell counting, after staining with 4',6-diamino-2-phenylindole (DAPI, final concentration $1 \mu \mathrm{g} \mathrm{mL}-1$ ) replicate samples were filtered onto $0.2 \mu \mathrm{m}$ pore-size polycarbonate membranes (Poretics, $25 \mathrm{~mm}$ diameter), and counted by epifluorescence microscope (Zeiss Axioplan equipped with an HBO $100 \mathrm{~W}$ lamp, a Neofluar $100 \mathrm{x}$ objective $1.25 \mathrm{x}$ additional magnification and filter sets for UV: BP365, FT 395, LP420). A minimum of 400 DAPI-stained cells per sample were counted on at least 10 fields.

\section{RESULTS}

\section{In situ dark $\left[{ }^{14} \mathrm{C}\right] \mathrm{HCO}_{3}$ uptake: testing the instrument}

We tested the functioning of a new device for in situ incubations at different stations (Ghiffa and Maggia) in Lake Maggiore at different depths and months. In order to compare the results obtained with the new device, classical on board incubations were performed concomitantly. Falcon ${ }^{\circledR}$ tubes for on board and syringes for in situ incubations were of the same volume and syringe tips large enough to sample particles or aggregates present in the water. We are thus confident that the two sample-types were comparable.

Dark $\left[{ }^{14} \mathrm{C}^{2} \mathrm{HCO}_{3}\right.$ uptake measured in situ ranged from 6.6 to $10.7 \mu \mathrm{g} \mathrm{C} \mathrm{m}^{-3} \mathrm{~h}^{-1}$ (mean coefficient of variation, $\mathrm{CV}=0.16$ ), whereas on board measurements ranged from 2.2 to $38 \mu \mathrm{g} \mathrm{C} \mathrm{m}^{-3} \mathrm{~h}^{-1}(\mathrm{CV}=0.89)$ with slightly higher mean (Fig. 2). The on board uptake measurements showed high spatial and temporal variability compared to the in

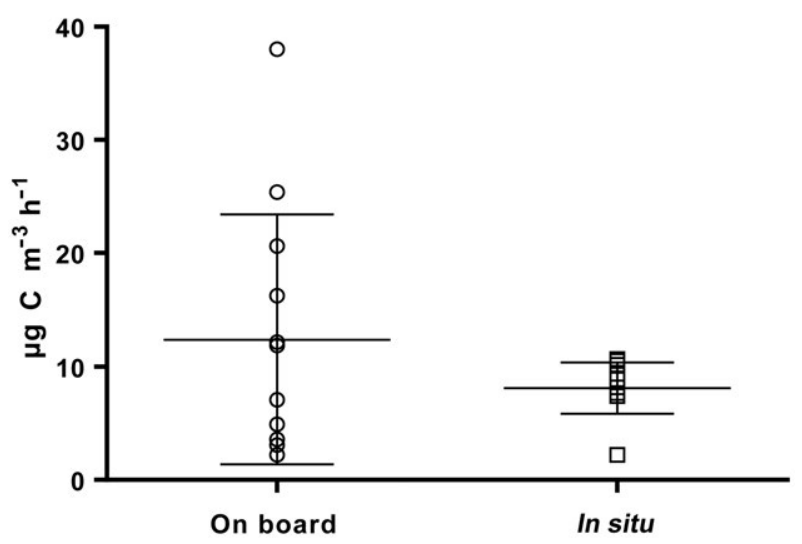

Fig. 2. Mean, standard deviation and single values of the dark $\left[{ }^{14} \mathrm{C}\right] \mathrm{HCO}_{3}$ uptake $\left(\mu \mathrm{g} \mathrm{C} \mathrm{m}^{-3} \mathrm{~h}^{-1}\right)$ obtained with on board and in situ incubations. 
situ incubations nevertheless, analyzed altogether the data of the two treatments were not significantly different (unpaired $t$-test, $\mathrm{df}=22, \mathrm{t}=1.308, \mathrm{P}=0.204$ ). The unpaired $t$ test performed per single depth showed significant differences at 200 and $300 \mathrm{~m}(\mathrm{P}=0.034$ and 0.024 respectively) and no significant differences at 100 and $350 \mathrm{~m}$ $(\mathrm{P}=0.093$ and 0.200 respectively).

\section{In situ dark $\left[{ }^{14} \mathrm{C}\right] \mathrm{HCO}_{3}$ uptake: Archaea vs Bacteria}

Dark $\left[{ }^{14} \mathrm{C}\right] \mathrm{HCO}_{3}$ uptake of Archaea was estimated by inhibiting the bacterial community in situ (Tab. 2). Measurements were performed with two custom-made devices at $350 \mathrm{~m}$ depth (Ghiffa), in August and October 2011. The non-bacterial daily uptake rates resulted in almost identical values in the two dates with an average of $52.7 \pm 0.4$ $\mu \mathrm{g} \mathrm{C} \mathrm{m} \mathrm{d}^{-3}$; this represents $28 \%$ of total dark uptake. Dark $\left[{ }^{14} \mathrm{C}\right] \mathrm{HCO}_{3}$ uptake values of Bacteria were higher both in August and October with an average value of 135.0 $\pm 15.6 \mu \mathrm{g} \mathrm{C} \mathrm{m}^{-3} \mathrm{~d}^{-1}$ (Tab. 2).

To estimate the bulk impact of dark $\left[{ }^{14} \mathrm{C}\right] \mathrm{HCO}_{3}$ uptake in the hypolimnion of Lake Maggiore we considered the aphotic water column from $20 \mathrm{~m}$ to $370 \mathrm{~m}$ depth. In this zone the mean total prokaryotic dark $\left[{ }^{14} \mathrm{C}\right] \mathrm{HCO}_{3}$ uptake was $65.8 \pm 5.2 \mathrm{mg} \mathrm{C} \mathrm{m}^{-2} \mathrm{~d}^{-1}$, with a non-bacterial uptake of $18.4 \pm 0.1 \mathrm{mg} \mathrm{C} \mathrm{m}^{-2} \mathrm{~d}^{-1}$ (Tab. 2).

\section{Thaumarchaeota and Bacteria in the deep hypolimnion}

Thaumarchaeota (probe Cren537) at $350 \mathrm{~m}$ constituted $10.2 \%$ of the total DAPI counts in August and $12 \%$ in October, resulting in cell numbers of 43 and $51 \times 10^{3}$ cells $\mathrm{mL}^{-1}$, respectively. Bacteria (probe EUB I-III) were $73.6 \%$ and $85.2 \%$, or 313 and $365 \times 10^{3}$ cells $\mathrm{mL}^{-1}$, in August and October, respectively.

\section{DISCUSSION}

The prokaryotic community inhabiting the hypolimnion is a crucial component of lake functioning but knowledge in respect to its activity is scarce. The aim of this study was to elucidate the role of Archaea in the autotrophic carbon fixation in a deep hypolimnion. In particular, we measured the dark $\left[{ }^{14} \mathrm{C}\right] \mathrm{HCO}_{3}$ uptake of the prokaryotic community inhabiting the deep hypolimnion (350 $\mathrm{m})$ of the large subalpine Lake Maggiore by direct in situ incubation performed with a custom-made device (Fig. 1). We were able to measure low activities of prokaryotes adapted to the dark, cold, and pressure conditions present at $350 \mathrm{~m}$, by avoiding sampling stresses. We made a comparison between in situ and on board incubations testing the device in different conditions ( 2 stations, 3 months, 4 depths). Interestingly, values of dark $\left[{ }^{14} \mathrm{C}\right] \mathrm{HCO}_{3}$ uptake measured in situ were similar in all the conditions ranging from 6.6-10.7 $\mu \mathrm{g} \mathrm{C} \mathrm{m}^{-3} \mathrm{~h}^{-1}$, while measurements on board showed high variability (Fig. 2). Considering that the hypolimnion is a stable environment not prone to high fluctuations, constant values of in situ measurements seemed to reflect the dark $\mathrm{CO}_{2}$ fixation better. Altogether the data sets of the on board and in situ incubations were not significantly different from each other. Taken separately per depth they were significantly different at 200 and $300 \mathrm{~m}$ and not different at 100 and $350 \mathrm{~m}$. Therefore, at present, our data do not support a difference between on board and in situ incubations. Actually the dark $\left[{ }^{14} \mathrm{C}\right] \mathrm{HCO}_{3}$ uptake technique and the protocol used were the same for the two incubation procedures. Nevertheless, the lower variation obtained render the in situ measurements more precise. In addition, the presented data are the first available on dark $\left[{ }^{14} \mathrm{C}\right] \mathrm{HCO}_{3}$ directly measured in situ at great depth.

The use of metabolic inhibitors allowed to measure total and non-bacterial dark $\mathrm{CO}_{2}$ assimilation in situ. As inhibitors of Bacteria we used allylthiourea that, at concentration of $86 \mu \mathrm{M}$, inhibits bacterial ammonium monooxygenase, by chelating the $\mathrm{Cu}$-active site of the Amo protein (Ginestet et al., 1998; Santoro and Casciotti, 2011); we also used sodium azide which is a bacteriostatic agent and an inhibitor of ammonia and nitrite oxidation (Mallmann et al., 1941; Ginestet et al., 1998). These metabolic inhibitors caused no significant decline in autotrophic activity of Archaea in the bathypelagic Mediterranean Sea (Yakimov et al., 2011) and in a hypertrophic saline lake (La Cono et al., 2013). Conversely, laboratory experiments (Santoro and Casciotti, 2011) evidenced that allylthiourea inhibited the rates of ammonia oxidation by a $58 \%$ at $86 \mu \mathrm{M}$ concentration after 40 days of incubation, whereas no effect on ammonia-oxidizing Archaea growth was observed within the first 48 hours of incubations (Santoro and Casciotti, 2011). Accordingly, the incubation period conducted in the present study should not have inhibited archaeal growth nor radiolabelled bicarbonate uptake. This consideration in the light of the demonstrated increase of Thaumarchaeota abundances with depth in Lake Maggiore (Callieri et al., 2009) indicate that the

Tab. 2. Bacteria and Archaea mean dark $\left[{ }^{14} \mathrm{C}\right] \mathrm{HCO}_{3}$ uptake at $350 \mathrm{~m}$ in Lake Maggiore, in August and October. Daily uptake was also calculated per surface $\left(\mathrm{mg} \mathrm{C} \mathrm{m}^{-2} \mathrm{~d}^{-1}\right)$, considering the aphotic water column from 20 to $370 \mathrm{~m}$.

\begin{tabular}{llcccc}
\hline \multirow{2}{*}{ Month } & \multirow{2}{*}{ Domain } & \multicolumn{2}{c}{$\mu \mathrm{g} \mathrm{m}^{-3} \mathrm{~d}^{-1}$} & \multicolumn{2}{c}{$\mathrm{mg} \mathrm{C} \mathrm{m}^{-2} \mathrm{~d}^{-1}$} \\
& Mean & $\pm \mathrm{sd}$ & \multicolumn{2}{c}{ Mean } & $\pm \mathrm{sd}$ \\
\hline \multirow{2}{*}{ August } & Bacteria & 146 & 49.6 & 51.1 & 17.4 \\
& Archaea & 52.4 & 13.9 & 18.3 & 10.2 \\
\hline \multirow{2}{*}{ October } & Bacteria & 124 & 18.0 & 43.6 & 6.5 \\
& Archaea & 53.0 & 18.4 & 18.5 & 6.5 \\
\hline
\end{tabular}

sd, standard deviation. 
non-bacterial $\mathrm{CO}_{2}$ uptake may be assigned to Archaea, likely belonging to Thaumarchaeota.

The estimate of $\left[{ }^{14} \mathrm{C}\right] \mathrm{HCO}_{3}$ uptake in the deep hypolimnion of Lake Maggiore was $187.7 \pm 15 \mu \mathrm{g} \mathrm{C} \mathrm{m}^{-3} \mathrm{~d}^{-1}$, substantially higher than reported for a hypertrophic saline lake (6-51 $\left.\mathrm{g} \mathrm{C} \mathrm{m}^{-3} \mathrm{~d}^{-1}\right)$ (La Cono et al., 2013). Moreover, our rates were higher than in the Mediterranean deep-sea (50-60 $\mu \mathrm{g} \mathrm{C} \mathrm{m}^{-3} \mathrm{~d}^{-1}$ at $2000 \mathrm{~m}$ ) (Yakimov et al., 2011) and in line with Levantine Intermediate Water (230

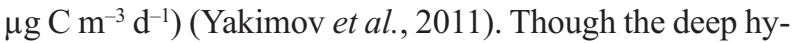
polimnion of Lake Maggiore is undoubtedly shallower than the marine bathypelagic zone, a comparison of the two zones is meaningful as they are both dark, cold, oxygenated, and oligotrophic diluted water masses with bottom sediment boundaries. Moreover, the relevance of dark $\mathrm{CO}_{2}$ uptake in freshwater deep hypolimnetic zones opens a new perspective on the role of prokaryotes as a sink for inorganic carbon. Our results indicate a predominant role of Bacteria with respect to Archaea in the dark $\mathrm{CO}_{2}$ fixation: the former being responsible for $72 \%$ of total dark $\mathrm{CO}_{2}$ uptake and the latter for the remaining $28 \%$.

Although there is evidence of autotrophic ammonia oxidation of Archaea (Herndl et al., 2005; Ingalls et al., 2006) their heterotrophic or mixotrophic growth cannot be excluded (Ouverney and Fuhrman, 2000; Teira et al., 2006) and it has even been proposed as the prevalent metabolism in Archaea (Agogué et al., 2008). With the method used in our work we cannot specify which metabolic pathways were used by prokaryotes in the deep hypolimnion. We are aware of the fact that prokaryotes can also use bicarbonate for anaplerotic reactions to replenish TCA cycle intermediates (Romanenko, 1964), or for the synthesis of amino acids and biosynthesis of fatty acids and that therefore our dark $\mathrm{CO}_{2}$ fixation measurements may also include these activities.

We measured the relative importance of Bacteria and Thaumarchaeota at $350 \mathrm{~m}$ in Lake Maggiore using CARD-FISH. To detect and enumerate Bacteria we used the mix EUBI-III which includes two additional probes complementary to Eub338: Eub338 II and III that target members of Verrucomicrobia and Planctomycetales (Daims et al., 1999). To identify Thaumarchaeota we avoided to use the general probe Arch915 which unspecifically binds to some bacteria (Pernthaler et al., 2002) and picocyanobacteria (Callieri, unpublished results), thus, would greatly overestimate the number of Archaea. We instead used the probe Cren537 which specifically targets the Thaumarchaeota MGI.1a clade ( $95.1 \%$ coverage, $0.2 \%$ outgroup hits) (Teira et al., 2004, 2006; Callieri et al., 2009). The finding that in a deep alpine lake up to $90 \%$ of the $16 \mathrm{~S}$ rRNA gene sequences of Thaumarchaeota belonged to MGI.1a and SAGMGC1 , the former being prevalent in the deep layers (Auguet et al., 2012) supports our choice of the probe targeting
Thaumarchaeota. Moreover, MGI.1a sequences have been found to dominate the archaeal assemblage of the oxygenated layer of a saline lake (La Cono et al., 2013). Nevertheless we cannot exclude that we were not able to detect all Archaea, as also Euryarchaeota play a role in freshwater habitats. However, these microbes seem to be more important in lakes with a higher trophic status (Auguet and Casamayor, 2013) or in anoxic water layers of a saline lake (La Cono et al., 2013). In general, CARD-FISH hybridization rates were in the range of other lake profiles (Salcher et al., 2011), suggesting that no substantial part of the community was missed.

To gain better insight into the relevance of dark $\mathrm{CO}_{2}$ fixation for lake ecosystem functioning, we compared the photosynthetic $\mathrm{CO}_{2}$ fixation in the photic zone of Lake Maggiore (Callieri and Piscia, 2002) with the dark $\mathrm{CO}_{2}$ fixation in the aphotic zone. The average primary production, measured in a time series study in 2002 by performing 15 measurements at 5 different depths in the euphotic zone of Lake Maggiore, was $483 \mathrm{mg} \mathrm{C} \mathrm{m}^{-2} \mathrm{~d}^{-1}$ (E. Caravati, unpublished data), while the average dark $\mathrm{CO}_{2}$ fixation in the aphotic zone was $66 \mathrm{mg} \mathrm{C} \mathrm{m}^{-2} \mathrm{~d}^{-1}$ (Table 2). Despite the different extension of the euphotic $(0-20 \mathrm{~m})$ and the aphotic (20-370 m) zone, the dark fixation corresponds to $14 \%$ of the total photosynthetic fixation. This comparison is imbalanced, as it also includes eukaryotic phototrophic activity (i.e., algae). If only prokaryotic activities are considered, the ratio photosynthetic:dark $\mathrm{CO}_{2}$ fixation is 1.2 , and the percentage of dark $\mathrm{CO}_{2}$ fixation corresponds to $87 \%$ of the pico-phytoplankton production (average: $76 \mathrm{mg} \mathrm{C} \mathrm{m}^{-2} \mathrm{~d}^{-1}$; E. Caravati, unpublished data). This value is only slightly higher than a 1:1 photosynthetic:dark $\mathrm{CO}_{2}$ fixation ratio reported from the Mediterranean Sea (Yakimov et al., 2011), although the extension of the aphotic zone is larger in the Mediterranean Sea than in Lake Maggiore (200-3480 m vs 20-370 m). Furthermore, the photic layer in the Mediterranean Sea is ultraoligotrophic, thus, phototrophic $\mathrm{CO}_{2}$ fixation rates are much lower than in Lake Maggiore.

\section{CONCLUSIONS}

Our study provides the first direct estimate of the in situ dark $\mathrm{CO}_{2}$ fixation conducted by prokaryotes in the deep hypolimnion of an oligotrophic lake. Our results point out that freshwater deep hypolimnia, although often disregarded, are places of important microbial metabolisms of the carbon and nitrogen cycle, and dark $\mathrm{CO}_{2}$ fixation rates are even comparable with the photosynthetic fixation occurring in photic zones.

\section{ACKNOWLEDGMENTS}

We thank G. Corno (CNR-ISE, Italy), J. Pernthaler (University of Zurich, Switzerland), B. Modenutti and E. 
Balseiro (CONICET, University of Comahue, Argentina) for their participation to discussion and sampling. M. Contesini (CNR-ISE, Italy) is acknowledged for his valuable work in the field and for DIC analyses, and E. Loher (University of Zurich, Switzerland) for building a prototype of the in situ sampler. Part of the research on Lake Maggiore was funded by the International Commission for the Protection of Italian-Swiss Waters (CIPAIS).

\section{REFERENCES}

Agogué H, Brink M, Dinasquet J, Herndl GJ, 2008. Major gradients in putatively nitrifying and not-nitrifying Archaea in the deep North Atlantic. Nature 456:788-791.

Amann R, Fuchs BM, 2008. Single-cell identification in microbial communities by improved fluorescence in situ hybridization techniques. Nat. Rev. Microbiol. 6:339-348.

Ambrosetti W, Barbanti L, 1999. Deep water warming in lakes: an indicator of climatic change. J. Limnol. 58:1-9.

Ambrosetti W, Barbanti L, Sala N, 2003. Residence time and physical processes in lakes. J. Limnol. 62:1-15.

Auguet JC, Casamayor EO, 2013. Partitioning of Thaumarchaeota populations along environmental gradients in high mountain lakes. FEMS Microbiol. Ecol. 84:154-164.

Auguet JC, Triadó-Margarit X, Nomokonova N, Camarero L, Casamayor EO, 2012. Vertical segregation and phylogenetic characterization of ammonia-oxidizing Archaea in a deep oligotrophic lake. ISME Journal 6:1786-1797.

Berg IA, Kockelkorn D, Buckel W, Fuchs G, 2007. A 3-hydroxypropionate/4-hydroxybutyrate autotrophic carbon dioxide assimilation pathway in Archaea. Science 318:1782-1786.

Bertoni R, Callieri C, Corno G, Rasconi S, Caravati E, Contesini M, 2010. Long-term trends of epilimnetic and hypolimnetic bacteria and organic carbon in a deep holo-oligomictic lake. Hydrobiologia 644:279-287.

Bertoni R, Piscia R, Callieri C, 2004. Horizontal heterogeneity of seston, organic carbon and picoplankton in the photic zone of Lago Maggiore, Northern Italy. J. Limnol. 63:244-249.

Brochier-Armanet C, Boussau B, Gribaldo S, Forterre P, 2008. Mesophilic Crenarchaeota: proposal for a third archaeal phylum, the Thaumarchaeota. Nat. Rev. Microbiol. 6:245-252.

Callieri C, Corno G, Caravati E, Rasconi S, Contesini M, Bertoni R, 2009. Bacteria, Archaea and Crenarchaeota in the epilimnion and hypolimnion of a deep holo-oligomictic lake. Appl. Environ. Microbiol. 75:7298-7300.

Callieri C, Piscia R, 2002. Photosynthetic efficiency and seasonality of autotrophic picoplankton in Lago Maggiore after its recovery. Freshwater Biol. 47:941-956.

Callieri C, Stockner JG, 2002. Freshwater autotrophic picoplankton: a review. J. Limnol. 61:1-14.

Casamayor E, Llirós M, Picazo A, Barberán A, Borrego CM, Camacho A, 2012. Contribution of deep dark fixation processes to overall $\mathrm{CO}_{2}$ incorporation and large vertical changes in microbial populations in stratified karstic lake. Aquat. Sci. 74:61-75.

Daims H, Brühl A, Amann R, Schleifer KH, Wagner M, 1999. The domain-specific probe EUB338 is insufficient for the detection of all Bacteria: development and evaluation of a more comprehensive probe set. Syst. Appl. Microbiol. 22:434-444.
Dokulil MT, Jagsch A, George GD, Anneville O, Jankowski T, Wahl B, Lenhart B, Blenckner T, Teubner K, 2006. Twenty years of spatially coherent deepwater warming in lakes across Europe related to the North Atlantic Oscillation. Limnol. Oceanogr. 51:2787-2793.

Ginestet P, Audic JM, Urbain V, Block JC, 1998. Estimation of nitrifying bacterial activities by measuring oxygen uptake in the presence of the metabolic inhibitors allylthiourea and azide. Appl. Environ. Microbiol. 64:2266-2268.

Herndl GJ, Reinthaler T, Teira E, Van Aken H, Veth C, Pernthaler A, Pernthaler J, 2005. Contribution of Archaea to total prokaryotic production in the deep Atlantic Ocean. Appl. Environ. Microbiol. 71:2303-2309.

Ingalls AE, Shah SR, Hansman RL, Aluwihare LI, Santos GM, Druffel ERM, Pearson A, 2006. Quantifying archaeal community autotrophy in the mesopelagic ocean using natural radiocarbon. PNAS 103:6442-6447.

Karner MB, DeLong EF, Karl DM, 2001. Archaeal dominance in the mesopelagic zone of the Pacific Ocean. Nature 409:507-510.

Keough BP, Schmidt TM, Hicks RE, 2003. Archeal nucleic acids in picoplankton from Great Lakes on three continents. Microb. Ecol. 46:238-248.

La Cono V, La Spada G, Arcadi E, Placenti F, Smedile F, Ruggeri G, Michaud L, Raffa C, De Domenico E, Sprovieri M, Mazzola S, Genovese L, Giuliano L, Slepak VZ, Yakimov MM, 2013. Partaking of Archaea to biogeochemical cycling in oxygen-deficient zones of meromictic saline Lake Faro (Messina, Italy). Environ. Microbiol. 15:1717-1733.

Mallmann WL, Botwright WE, Churchill ES, 1941. The selective bacteriostatic effect of slow oxidizing agents. J. Inf. Dis. 69:215-219.

Newton RJ, Jones SE, Eiler A, McMahon KD, Bertilsson S, 2011. A guide to the natural history of freshwater lake bacteria. Microbiol. Mol. Biol. Rev. 75:14-49.

Okazaki Y, Hodoki Y, Nakano S, 2013. Seasonal dominance of CL500-11 bacterioplankton (phylum Chloroflexi) in the oxygenated hypolimnion of Lake Biwa, Japan. FEMS Microbiol. Ecol. 83:82-92.

Ouverney CC, Fuhrman JA, 2000. Marine planktonic Archaea take up amino acids. Appl. Environ. Microbiol. 66:4829-4833.

Pernthaler A, Pernthaler J, Amann R, 2004. Sensitive multi-color fluorescence in situ hybridization for the identification of environmental microrganisms, p. 711-726. In: A.D.L. Akkermans, F.J. de Bruijn and J.D. van Elsas (eds.), Molecular microbial ecology manual, $2^{\text {nd }}$ ed. Kluwer Academic Publ., Dordrecht.

Pernthaler A, Preston CM, Pernthaler J, DeLong EF, Amann R, 2002. Comparison of fluorescently labeled oligonucleotide and polynucleotide probes for the detection of pelagic marine Bacteria and Archaea. Appl. Environ. Microbiol. 62:661-667.

Pester M, Christa S, Wagner M, 2011. The Thaumarchaeota: an emerging view of their phylogeny and ecophysiology. Curr. Opin. Microbiol. 14:300-306.

Romanenko WI, 1964. [Heterotrophic assimilation of $\mathrm{CO}_{2}$ by the aquatic microflora]. [Article in Russian]. Mikrobiologiia 33:679-683.

Salcher MM, Pernthaler J, Frater N, Posch T, 2011. Vertical and longitudinal distribution patterns of different bacterioplank- 
ton populations in a canyon-shaped, deep prealpine lake. Limnol. Oceanogr. 56:2027-2039.

Salmaso N, Buzzi F, Garibaldi L, Morabito G, Simona M, 2012. Effects of nutrient availability and temperature on phytoplankton development: a case study from large lakes south of the Alps. Aquat. Sci. 74:555-570.

Salmaso N, Morabito G, Buzzi F, Garibaldi L, Simona M, Mosello R, 2006. Phytoplankton as an indicator of the water quality of the deep lakes south of the Alps. Hydrobiologia 563:167-187.

Santoro AE, Casciotti KL, 2011. Enrichment and characterization of ammonia-oxidizing Archaea from the open ocean: phylogeny, physiology and s isotope fractionation. ISME J. 5:1796-1808.

Schattenhofer M, Fuchs BM, Amann R, Zubkov MV, Tarran GA, Pernthaler J, 2009. Latitudinal distribution of prokaryotic picoplankton populations in the Atlantic Ocean. Environ. Microbiol. 11:2078-2093.

Steeman-Nielsen E, 1951. Measurement of the production of organic matter in the sea by means of carbon-14. Nature 167:684-685.

Teira E, Reinthaler T, Pernthaler A, Pernthaler J, Herndl GJ, 2004. Combining catalyzed reporter deposition-fluorescence in situ hybridization and microautoradiography to detect substrate utilization by Bacteria and Archaea in the deep ocean. Appl. Environ. Microbiol. 70:4411-4414.

Teira E, van Aken H, Veth C, Herndl GJ, 2006. Archaeal uptake of enantiomeric amino acids in the meso- and bathypelagic waters of the North Atlantic. Limnol. Oceanogr. 51:60-69.

Urbach E, Vergin KL, Young L, Morse A, Larson GL, Giovannoni SJ, 2001. Unusual bacterioplankton community structure in ultra-oligotrophic Crater Lake. Limnol. Oceanogr. 46:557-572.

Venter JC, Remington K, Heidelberg JF, Halpern AL, Rusch D, Eisen JA, Wu D, Paulsen I, Nelson KE, Nelson W, Fouts DE, Levy S, Knap AH, Lomas MW, Nealson K, Ehite O, Peterson J, Hoffman J, Parsons R, Baden-Tillson H, Pfannkoch C, Rogers YH, Smith HO, 2004. Environmental genome shotgun sequencing of the Sargasso Sea. Science 304:66-74.

Yakimov MM, La Cono V, Smedile F, DeLuca TH, Juárez S, Ciordia S, Fernández M, Albar JP, Ferrer M, Golyshin PN, Giuliano L, 2011. Contribution of crenarchaeal autotrophic ammonia oxidizers to the dark primary production in Tyrrhenian deep waters (Central Mediterranean Sea). ISME J. 5:945-961.

Zeder M, Pernthaler J, 2009. Multispot live-image autofocusing for high-throughput microscopy of fluorescently stained bacteria. Cytometry A 75A:781-788. 